
\author{
старш. наук. співроб. науково-дослідної частини, \\ Західноукраїнський національний університет, м. Тернопіль

\section{ІНСТРУМЕНТАРІЙ РЕГУЛЮВАННЯ РИНКІВ СІЛЬСЬКОГОСПОДАРСЬКОЇ ПРОДУКЦІЇ В УМОВАХ ЕКОНОМІЧНОÏ НЕВИЗНАЧЕНОСТІ}

Горлачук М.A., канд. екон. наук, доцент,

Horlachuk M.A.,

cand.sc.(econ.), assoc. prof., senior research fellow of scientific and research part, West Ukrainian National University, Ternopil

\title{
TOOLS FOR REGULATING MARKETS OF AGRICULTURAL PRODUCTS IN CONDITIONS OF ECONOMIC UNCERTAINTY
}

Постановка проблеми. Висновки класиків політичної економії стосовно «невидимої руки ринку», котра, незважаючи на те, що окремі люди переслідують не суспільні, а свої власні інтереси, завжди призводить до оптимального результату, слід нині сміливо віднести до тієї частини ще й досі існуючої теоретичної есхатології економічних досліджень про переваги вільного ринку, які вже протягом тривалого історичного періоду не лише не підтверджуються фрактами суспільного розвитку, а й прямо суперечать дійсності.

Економічна доктрина laissez-faire давно перетворилася на догму, особливо яскраво проявившись у своїй радикальній вимозі вільної торгівлі. Здається, в цій історії давно повинен поставити крапку Дж. Кейнс зі своєю працею «Кінець laissez-faire»: «Протягом більш ніж столітнього періоду філософи володіли нашими умами, оскільки якимось дивом майже всі вони були згідні (або ж здавалося, що були згідні) з ідеями laissez-faire. Багато в чому ситуація залишилася такою, якою й була. Проте, зміни ширяють в повітрі» [1, с. 260].

Насправді із тієї пори теоретичного висновку Дж. Кейнса про ймовірні економічні зміні відбулися настільки вражаючі практичні перетворення в організації ринку, що, очевидно, втратив своє значення не лише принцип laissez-faire, а й поставлено під сумнів сам ринок як фундаментальну до цих пір інституцію реалізації товарообміну в процесі економічного відтворення.

Ринковий механізм регулювання аграрного виробництва виявився недосконалим через так звані «провали ринку», що здатні посилюватися сезонністю виробництва сільськогосподарської продукції, погодними ризиками, біологічними особливостями розвитку організмів, значною ціновою волатильністю та сукупністю інших чинників, котрі формують так звану економічну невизначеність загалом, негативні наслідки якої можуть бути усунуті чи пом'якшені лише через застосування відповідних інструментів регулювання ринку та управління ним з боку держави.

Аналіз останніх досліджень і публікацій. Тема представленої статті $€$ багатоаспектною, тобто вимагає аналізу і теоретичних узагальнень із таких важливих дослідницьких напрямків, котрі присвячені з'ясуванню сутності не лише окремих складових її назви - ринків сільськогосподарської продукції, інструментарію регулювання чи економічної невизначеності, а передусім їх реальної системної взаємодії, наслідком якої постає емерджентність, дійсний процес регулювання розвитку ринків сільськогосподарської продукції, головним чином, ключових із них, в умовах перманентного подолання невизначеності з метою задоволення практичних суспільних потреб.

У вказаному контексті слід відмітити наукові розвідки В. Андрійчука, О. Грабчука, А. Діброви, В. Зіновчука, Т. Зінчук, С. Кваші, Ю. Лупенка, С. Майстро, Ю. Ольсевича, П. Макаренка, М. Маліка, В. Месель-Веселяка, Б. Пасхавера, Н. Резнік, П. Саблука, О. Супрун, А. Стельмащука, В. Онегіної, Т. Осташко, І. Охріменка, Г. Черевка, О. Шпикуляка, О. Шпичака, В. Юрчишина та інших вітчизняних і зарубіжних учених, присвячених досліджуваній темі.

Значний вклад у розробку теорії невизначеності зробили Ф. Найт [2] та Л. Мізес [3]. Вони розглядали невизначеність гносеологічно, розкрили таке поняття як «незрозумілість», категоріально виокремивши також поняття «невизначеність» і «ризик», поряд із Дж. Кейнсом обґрунтували природу невизначеності, наслідки та необхідність її усунення.

Праці цих вчених вважаються ґрунтовними, однак залишаються недостатньо дослідженими проблеми використання інструментів регулювання ринків сільськогосподарської продукції в сучасних 
умовах швидких змін середовища і значного ступеня невизначеності [4], в тому числі зумовлених впливом COVID-19 на економіки країн світу в глобальному вимірі.

Постановка завдання. Метою статті $€$ теоретико-методологічне обґрунтування інструментарію регулювання ринків сільськогосподарської продукції в умовах економічної невизначеності та можливих моделей їх застосування на стратегічно важливих аграрних ринках.

Виклад основного матеріалу дослідження. Як відомо, ринки сільськогосподарської продукції слугують обміну товарами в межах різних за величиною територіальних утворень, що можуть бути зовсім малими за розміром, або ж, навпаки, поширюватися за межі окремих країн, перетворившись на глобальні ринки для окремих видів сільськогосподарської продукції.

У доіндустріальний період аграрний ринок виконував доповнювальну функцію, оскільки переважний обсяг виробленої продукції споживався самими ж товаровиробниками, не потрапляючи через вказані обставини на ринок. Досліджуючи еволюцію ринку сільськогосподарської продукції, важливо розрізняти два його особливих випадки: 1) ринок як інституційну систему економічної організації суспільства (ринкової економіки) та 2) ринок як місце, площу, де в певний час щотижня чи щорічно (ярмарка) зустрічалися продавці та покупці сільськогосподарської продукції. Справедливо відзначити, що в останньому випадку, де важливе значення належить територіальній ідентифікації ринку як конкретного місця, організацію товарообміну слід віднести, як правило, до неринкової. Натомість, ринкова економіка - це такий економічний порядок, за якого обмінні процеси відбуваються завдяки ринку і координуються через дію його цінового механізму.

Слід зауважити, нині майже усі ринки сільськогосподарської продукції зазнають негативного впливу зростаючої цінової волатильності внаслідок глобалізації та лібералізації, що мають місце протягом останніх 30 років. Окрім того, до причин вказаного стану дослідники все більше відносять явища, зумовлені зміною погоди і клімату - посухи, повені чи різкі похолодання, які суттєво впливають на економічну невизначеність розвитку ринків сільськогосподарської продукції, в тому числі у світовому масштабі.

На думку низки науковців, невизначеність представляє собою неусувну характеристику ринкового середовища. Вона пов'язана з тим, що ринкові умови зазнають впливу великої кількості фракторів різної природи і спрямованості, котрі не можна об'єктивно оцінити та врахувати в кількісному вираженні [5, с. 30].

Цей висновок є практично утилітарний, оскільки він справедливий також для різних типів економічних систем. Так, в колишньому СРСР науковцями було обґрунтовано так звану оптимальну систему ситуаційних економічних нормативів як складову економіки оптимального погодного ризику, оскільки, наприклад, за роки останніх п'ятирічок діапазон коливання виробництва зерна в країні склав понад 50 млн т (24\% середньорічного збору урожаю), а в зонах посух погодні коливання об'ємів виробництва сільськогосподарської продукції набагато перевищували зазначені середні величини [6, C. 5-7].

Таким чином, економічна невизначеність ринку, зумовлена, до того ж, іншими кризовими явищами його розвитку, створює суттєві ризики для підприємництва, що логічно трактувати їх як міру невизначеності. Це дає підстави дослідникам стверджувати про фундаментальну невизначеність ринку [7].

У зв'язку з цим, економічною наукою та аграрною політикою держав впроваджуються стратегії, моделі регулювання ринків сільськогосподарської продукції, що базуються на використанні конкретних інструментів, котрі, своєю чергою, залежать від методів реалізації регуляторної політики. До останніх відносять економічні, адміністративні та правові.

В Україні економічні методи регулятивного впливу на ринки сільськогосподарської продукції передбачають застосування інструментів бюджетно-податкової, грошово-кредитної, митної, цінової політики, в тому числі з метою формування необхідних протекціоністських заходів.

До адміністративних інструментів реалізації регуляторної аграрної політики належить ліцензування, квотування, стандартизація і сертифікація, державні замовлення та контракти, адміністративні заборони й обмеження, регламентація діяльності учасників ринку сільськогосподарської продукції та ін.

Правові методи регулювання ринків базуються на застосуванні законів, указів Президента України, постанов КМУ, розпоряджень міністрів, відомств, комітетів, рішення місцевих органів влади тощо.

Формування i забезпечення сталого розвитку аграрного ринку завжди відносилося до пріоритетних завдань української влади, а організація прозорого аграрного ринку розглядалася як важливий інструмент поліпшення його соціально-економічного стану. Так, ліквідація системи державних закупівель сільськогосподарської продукції у 90-их роках минулого століття призвела до тінізації функціонування сільськогосподарських ринків, що було викликано, 3 одного боку, неспроможністю старої інфраструктури реалізації продукції забезпечити ефективне функціонування ринку та, з другого боку, появою значної кількості комерційних посередницьких структур, які використовували непрозорі схеми закупівлі та продажу сільськогосподарської продукції. 
3 метою розв'язання цієї проблеми і створення спеціалізованої ринкової інфраструктури, що забезпечувала б прозорість процедур купівлі-продажу на аграрному ринку, в червні 2000 р. Президентом України видано Указ «Про заходи щодо забезпечення формування і фрункціонування аграрного ринку» [8], а ще раніше, у 1995 р., президентським Указом «Про заходи щодо реформування аграрних відносин» [9] було підтримано ініціативу сільськогосподарських товаровиробників стосовно створення системи спеціалізованих аграрних бірж і запроваджено біржову торгівлю аграрною продукцією.

Аграрна біржа як організований ринок сільськогосподарської продукції покликана забезпечити прозорість товарообмінних операцій, бути генератором ринкового ціноутворення, суттєво зменшуючи економічну невизначеність, створюючи належні економічні умови для товаровиробників і покупців.

Приклад регулювання ринків сільськогосподарської продукції в Європейському Союзі засвідчує позитивний досвід функціонування спеціалізованих аграрних бірж як інструменту концентрації ринку і його транспарентності, зменшення волатильності цін.

Однак, слід зауважити, сучасне регулювання ринків сільськогосподарської продукції в $€ С$ зводиться до перенесення акцентів підтримки на соціальні і екологічні аспекти. Одержання прямих виплат, не пов'язаних з сільськогосподарським виробництвом, в практичному плані реалізується через комплексну, масштабну програму соціального розвитку сільської місцевості з відповідним розвитком матеріальної та інтелектуальної інфрраструктури на селі.

Проте й досі головним чинником забезпечення належного рівня доходів і соціального благополуччя фрермерів залишається фрінансова підтримка 3 аграрного бюджету $€$. Вона $€$ вирішальною соціальною функцією та фінансовим інструментом Спільної аграрної політики, хоча розмір бюджетної підтримки сільськогосподарського сектору протягом останніх 20 -ти років скоротився із 90\% в кінці 60-их років минулого століття до майже $40 \%$ загального обсягу бюджету Євросоюзу нині.

В Україні на особливу увагу як з боку науковців, так і з боку профрільних структур державних органів влади заслуговує негайне вирішення проблем розвитку ринку яловичини, що перебуває сьогодні в надзвичайно кризовому стані. Саме біржову діяльність у сфрері м'ясного скотарства потрібно розглядати як один із основних способів адаптації товаровиробників до постійних змін внутрішнього та зовнішнього середовища, усунення економічної невизначеності. Спільна господарська діяльність учасників ринкового процесу забезпечить стабільний розвиток м'ясного скотарства в Україні та підвищить конкурентоспроможність вітчизняної продукції яловичини на світових ринках. Нами пропонується наступна модель розвитку ринку яловичини в Україні (рис. 1).

Створення біржі ВPX 3 наступним формуванням організованого ринку яловичини має відбуватись на основі впровадження інтегрованої системи безпечності та якості продукції, а також єдиної платформи електронної торгівлі за безпосередньої участі товаровиробників, представляючи собою ключовий інституційний чинник впровадження сучасного економічного механізму регулювання ринку яловичини в державі.

Інфрраструктура ринкового кластеру - це сукупність підприємств, організацій, що діють на ринку яловичини з метою задоволення потреб споживачів та отримання прибутку. Кластери скорочують свої витрати завдяки спільній технологічній діяльності, вони фрормують спеціальний економічний простір. Ці об'єднання є джерелами і чинниками економічного зростання.

Впровадження моделі позначиться на всіх аспектах розвитку ринку яловичини, поступово має відбуватися необхідний, обов'язковий перехід до оновленого економічного механізму, змінюючи саме ринкове середовище діяльності сільськогосподарських виробників та інших учасників ринку.

3 огляду на роль біржового напрямку в системі розвитку економічного механізму регулювання ринку яловичини, потрібно, передусім, розглянути фрінансовий аспект у ресурсному забезпеченні галузі м'ясного скотарства. Загальною метою фінансового забезпечення вказаної регуляторної моделі ринку яловичини $є$ розвиток інституційних відносин, підвищення самодостатності країни у продукції великої рогатої худоби, задоволення потреб споживачів. Фінансове забезпечення ринку яловичини як результату процесу реалізації економічного механізму його регулювання можливе за рахунок таких джерел:

- створення фонду, де учасниками будуть, з одного боку, держава, а з іншого - внески підприємств, що працюють на ринку;

- виділення необхідного розміру коштів із бюджету;

- проведення тендеру на розбудову інноваційної інфрраструктури, фрінансування якого можна здійснювати з державного бюджету на основі повернення;

- створення сприятливого інвестиційного клімату, який потрібно супроводжувати податковими «канікулами» та пільгами, котрі мають бути привабливі для того, щоб інвестори вкладали гроші в розвиток ринку яловичини.

Актуальним питанням у вдосконаленні економічного механізму регулювання ринку яловичини $\epsilon$ координування процесу розробки системи підтримки інноваційного розвитку. 


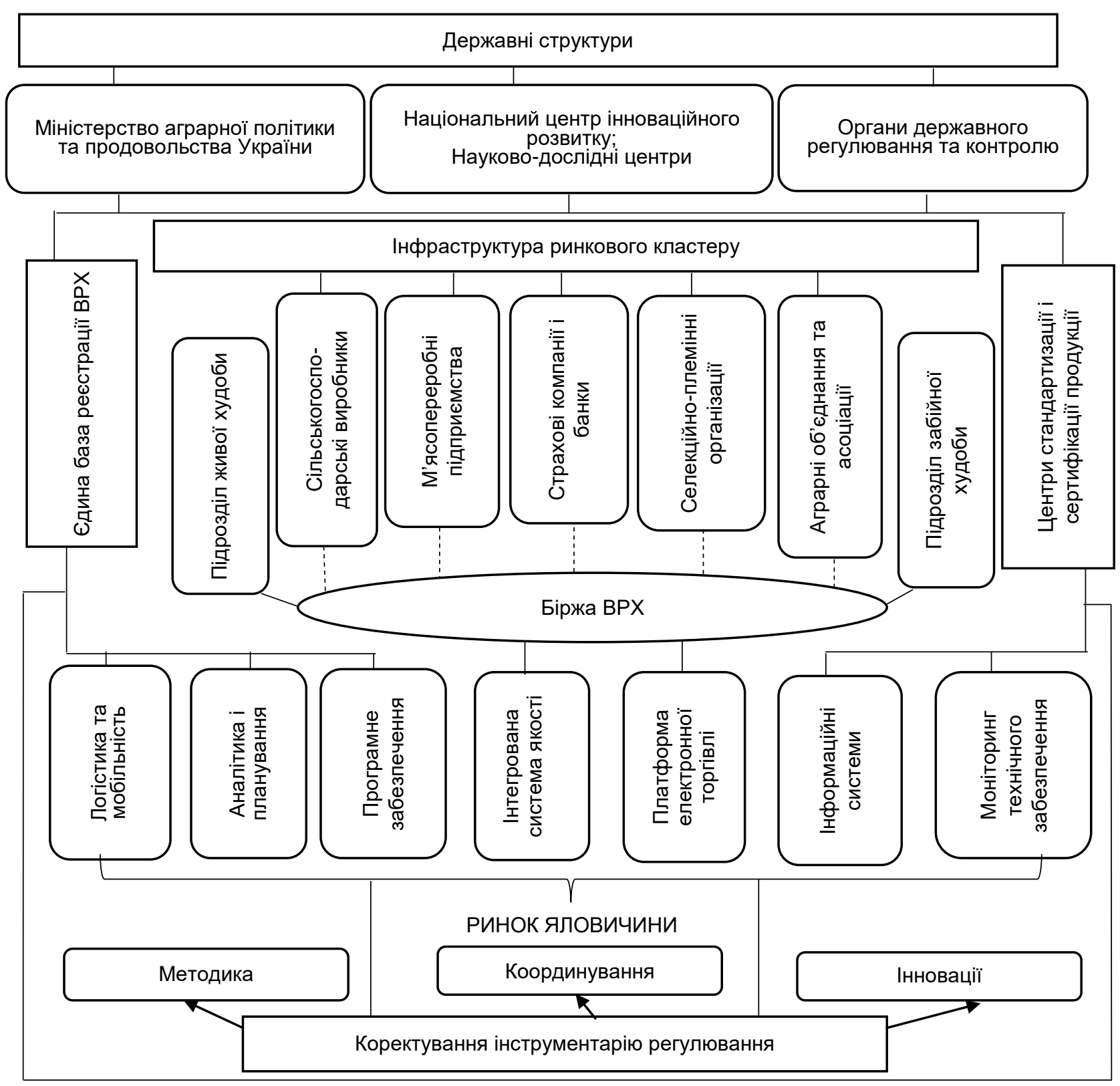

Рис. 1. Модель розвитку ринку яловичини в Україні

Джерело: складено автором на основі результатів дослідження

Біржа ВPX має стати спеціалізованим національним майданчиком організованого ринку сільськогосподарської продукції, структурно охоплюючи два підрозділи: а) живої худоби та б) забійної худоби. Засновниками біржі можуть бути держава, сільськогосподарські виробники м'яса ВРX, переробні підприємства, інші установи та організації, включаючи асоціативні фрормування.

Основними цілями національної біржі ВРX слід визначити:

1) формування i обслуговування вітчизняного ринку яловичини із врахуванням принципу мультифункціональності та забезпечення ринкової багатоманітності, що ґрунтується на виробництві окремих видів яловичини: м'яса молодняка худоби, бичків, нетелей та теличок, телятини, корів, включаючи в тому числі виробничі параметри за якісними характеристиками споживчого товару традиційне чи органічне виробництво продукції;

2) формування прозорого й оптимального ланцюга створення вартості м'яса яловичини, ваги живої та забійної худоби для українського скотарства, а також забезпечення необхідного рівня грошових доходів і рентабельності для товаровиробників;

3) культивування свідомого ставлення споживачів до необхідності забезпечення високої якості продукції м'ясного скотарства та культури її споживання.

Прикладом успішного інституційного регулювання ринку яловичини та його ефективного розвитку може слугувати досвід Австрії. Так, у 1996 р. спільними зусиллями членів-засновників, 
представників галузі скотарства, а також відгодівельних та переробних організацій, було засновано Австрійську біржу ВРX. Нині питома вага сегменту цієї біржі на ринку яловичини Австрії становить понад 35\%, при цьому близько 68\% худоби на забій вирощуються та реалізуються через біржовий механізм в рамках цільових програм забезпечення якості продукції.

На нашу думку, інтегрована система якості на українському ринку яловичини має виконувати вимоги забезпечення високої якості продукції, починаючи від ланки безпосереднього виробництва в галузі скотарства та закінчуючи сферою споживання кінцевої продукції (рис. 2). Забезпечення високої якості м'яса яловичини має супроводжуватись розробкою та дотриманням виконання вимог, що стосуються умов утримання худоби, починаючи, наприклад, від необхідності встановлення мінімальних норм за вільною площею у розрахунку на 1 голову худоби, яка утримується в закритому приміщенні та на вигулі. Особливо важливими мають стати нормативи щодо забезпечення кормами галузі скотарства, складу кормової бази у процесі дорощування і відгодівлі тварин, передусім це стосується дотримання обґрунтованих рівнів годівлі та структури раціонів для різних статево-вікових груп ВРX.

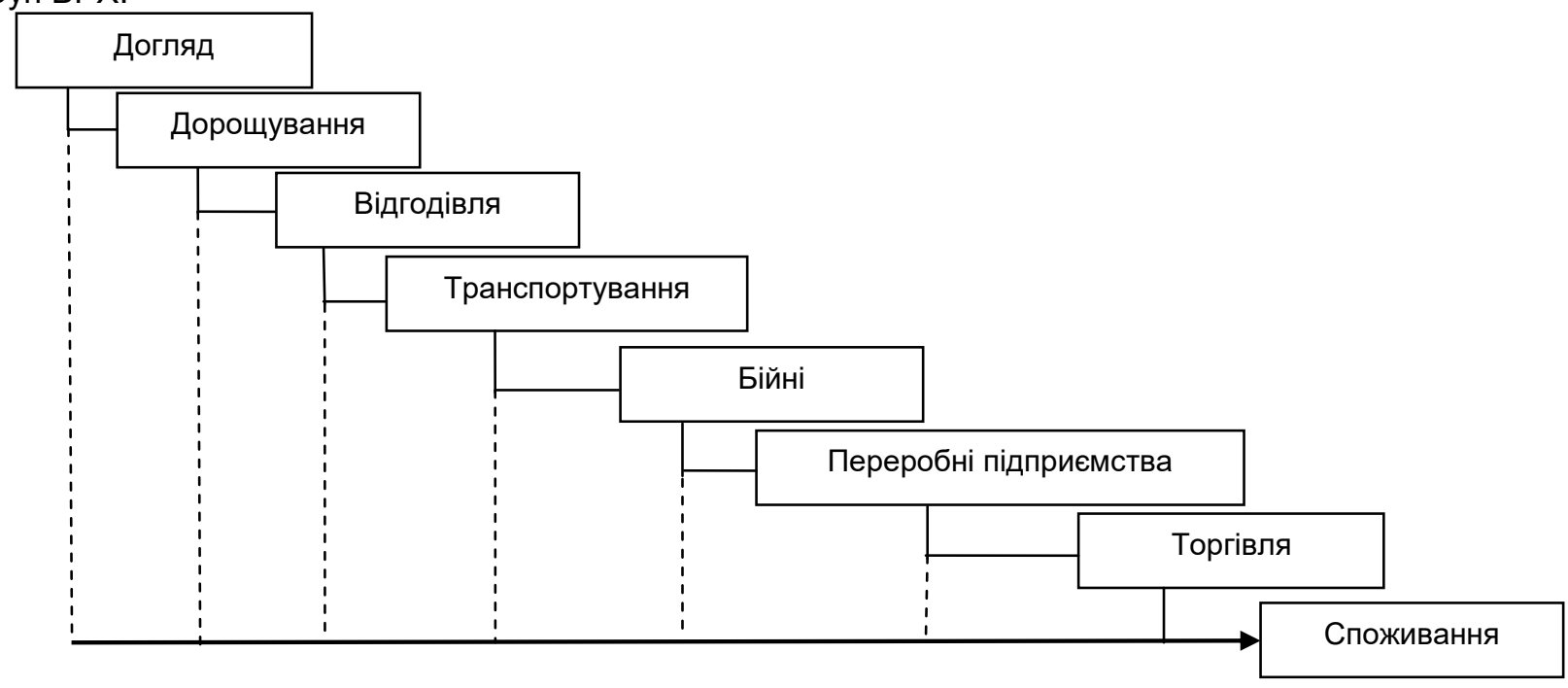

Рис. 2. Інтегрована система забезпечення якості продукції на ринку яловичини Джерело: складено автором на основі результатів дослідження

Основне завдання спеціалізованої товарної біржі полягає у формуванні прозорого механізму ціноутворення на ринку шляхом організованого збуту сільськогосподарської продукції через визначення реального співвідношення попиту і пропозиції на товари, створення належних умов для забезпечення прозорого товарообігу і пов'язаних із ним торгових операцій, а також страхування цінових ризиків від продажу біржових товарів в умовах системної невизначеності.

Висновки $з$ проведеного дослідження. Регулювання ринків сільськогосподарської продукції $\epsilon$ важливою комплексною складовою реалізації аграрної політики в Україні. Воно вимагає застосування різноманітної сукупності інструментів, адекватних поточним ринковим викликам, що ґрунтуються на розробці економічних, адміністративних та правових методів складного регуляторного механізму усунення або ж зниження економічної невизначеності, подолання якої в процесі прийняття агентами ринку підприємницьких рішень зумовлює, як наслідок, виникнення ризиків, що не завжди можуть бути з достатньою вірогідністю передбачені.

Формування організованого ринку сільськогосподарської продукції належить до важливих стратегічних завдань управління та інституційного регулювання цільових товарних ринків. За сучасних глобалізаційних тенденцій розвитку вітчизняної аграрної економіки функціонування спеціалізованих біржових майданчиків сприяло б більшій доступності використання біржових інструментів учасниками ринку сільськогосподарської продукції з метою хеджування власних економічних ризиків.

\section{Література}

1. Кейнс Дж. Конец laissez-faire / перев. Е. В. Виноградова. Москва : ГУ-ВШЭ, 2001. С. 260-279.

2. Найт Ф. Х. Риск, неопределенность и прибыль. Москва : Дело, 2003. 360 с.

3. Мизес Л. Человеческая деятельность: Трактат по экономической теории. Москва : Экономика, 2000. 878 с.

4. Гончаренко І. В., Богославська А. В., Федоришина Л. М. Організаційно-економічний потенціал інноваційного підприємництва у стратегічному розвитку регіональної економіки України. Інноваційна економіка. 2021. № 1-2. С. 5-11. 
5. Грабчук О. М. Сутність та форми детерміністської невизначеності економічних процесів. Європейський вектор економічного розвитку. 2012. № 1(12). С. 30-37.

6. Кардаш В. А. Экономика оптимального погодного риска в АПК (теория и методы). Москва : Агропромиздат, 1989. 167 с.

7. ОльсевичЮ.Я. Фундаментальная неопределенность рынка и концепции современного кризиса. Москва : Институт экономики РАН, 2011. 51 с.

8. Про заходи щодо забезпечення формування і функціонування аграрного ринку : Указ

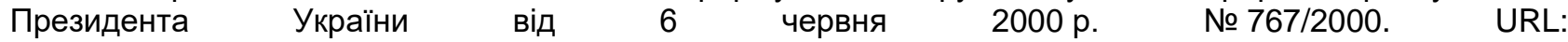
https://zakon.rada.gov.ua/laws/show/767/2000\#Text (дата звернення: 03.03.2021).

9. Про заходи щодо реформування аграрних відносин : Указ Президента України від 18 січня 1995 р. № 63/95. URL: https://zakon.rada.gov.ua/laws/show/63/95\#Text (дата звернення: 03.03.2021).

\section{References}

1. Keynes, J. (2001), Konets laissez-faire [The end of laissez-faire], Translated by E.V. Vinogradov, GU-VShE, Moscow, Russia, pp. 260-279.

2. Knight, F.H. (2003), Risk, neopredelennost i pribyl [Risk, Uncertainty and Profit], Delo, Moscow, Russia, 360 p.

3. Mises, L. (2000), Chelovecheskaia deiatelnost: Traktat po ekonomicheskoy teorii [Human Activity: A Treatise on Economic Theory], Ekonomika, Moscow, Russia, 878 p.

4. Honcharenko, I.V., Bohoslavska, A.V. and Fedoryshyna, L.M. (2021), "Organizational and economic potential of the innovation administration in the strategic development of the regional economy of Ukraine", Innovatsiina ekonomika, no. 1-2, pp. 5-11.

5. Hrabchuk, O.M. (2012), "The essence and forms of deterministic uncertainty of economic processes", Yevropeiskyi vector ekonomichnoho rozvytku, no. 1(12), pp. 30-37.

6. Kardash, V.A. (1989), Ekonomika optimalnogo pogodnogo riska $v$ APK (teoriia $i$ metody) [Economics of optimal weather risk in the agro-industrial complex (theory and methods)], Agropromizdat, Moscow, Russia, 167 p.

7. Olsevich, Yu.Ya. (2011), Fundamentalnaia neopredelennost rynka i kontseptsii sovremennogo krizisa [Fundamental market uncertainty and the concept of the modern crisis], Institut ekonomiki RAN, Moscow, Russia, $51 \mathrm{p}$.

8. The President of Ukraine (2000), The Decree "On measures to ensure the formation and functioning of the agricultural market" dated 06.06 .2000 no. 767/2000, available at: https://zakon.rada.gov.ua/laws/show/767/2000\#Text (access date March 03, 2021).

9. The President of Ukraine (1995), The Decree "On measures to reform agricultural relations" dated 18.01.1995 no. 63/95, available at: https://zakon.rada.gov.ua/laws/show/63/95\#Text (access date March 03, 2021). 